\title{
Essential mint oil-based emulsions: preparation and characterization
}

\author{
ANGELA DĂNILĂ \\ CARMEN ZAHARIA \\ DANIELA ŞUTEU \\ EMIL IOAN MUREŞAN \\ GABRIELA LISĂ
}

DOI: 10.35530/IT.070.01.1581

\author{
SINEM YAPRAK KARAVANA \\ ALI TOPRAK \\ ALINA POPESCU \\ LAURA CHIRILĂ
}

\section{REZUMAT - ABSTRACT}

Emulsii obținute pe bază de ulei esențial de mentă: obținere și caracterizare

Scopul acestei lucrări este de a prezenta pe scurt metodologia de obținere a patru tipuri de emulsii $\left(M_{2}, M_{3}, M_{6}\right.$ și $\left.M_{7}\right)$ pe bază de ulei esențial de mentă (Mentha Piperita) și proprietățile fizico-chimice și calitative ale acestora ( $p H$, densitate, indice de aciditate, indice de peroxid, conținutul de diene și triene conjugate, stabilitatea în timp, conținutul de apă și materie grasă), cu scopul de a selecta varianta optimă de formulare a emulsiei pentru aplicare în domeniul textil. Această lucrare subliniază, de asemenea, faptul că cea mai stabilă este emulsia $M_{6}$ urmată de emulsia $M_{3}$.

Cuvinte-cheie: ulei esențial de mentă, ceară de albine, emulsie, proprietăți fizico-chimice și calitative

\section{Essential mint oil-based emulsions: preparation and characterization}

The aim of this work is to present briefly the preparation methodology of four emulsions (named $M_{2}, M_{3}, M_{6}$, and $M_{7}$ ) based on extracted mint oil (Mentha Piperita) and their physical-chemical properties and quality characteristics ( $\mathrm{pH}$, density, acidity index, peroxide index, diene and triene content, in-time stability, humidity and fatty matter content), in order to select the most recommendable emulsion to be used in textile field. This work also underlines that the most stable emulsion is $M_{6}$ emulsion followed by $M_{3}$ emulsion.

Keywords: mint essential oil, beeswax, emulsion; physical-chemical properties; quality characteristics

\section{INTRODUCTION}

Researches from last years have shown that aromatherapy textiles are increasingly used because of the benefits offered as: environmentally friendly and beneficial effects on wellbeing and human health.

Essential oils are a common source of bioactive ingredients and are used for their various functional properties (anti-inflammatory, anti-microbial, organoleptic, antioxidant, anti-arrhythmic, anti-thrombotic, antivasoconstrictive, anti-hypertension, anti-ulcerous, anti-aging, anti-carcinogen, anti-diabetic, anti-depressant, anti-pyretic, and insect repellent) [1]. In textile field, most essential oils are used for their antimicrobial effect [2].

Although skin is not a common way of managing biologically active principles due to difficult absorption especially for water-soluble substances, in recent years, more attention has been paid to the benefits of transdermal administration: controlled release of biologically active principles leading to reduced invasiveness; reduction of the metabolic stages in the liver; avoiding stomach trauma [3, 4].

Losses by evaporation and difficulties in controlling releases make the application of essential oils to be limited. In this case, carrier systems (lipid particles, nano-emulsions, biocompatible polymer particles) can provide an ideal solution to achieve a controlled and targeted distribution of essential oil.
Natural waxes are suitable for essential oils embedding [5]. Also, natural waxes are of food grade purity (insect waxes - bees wax and plant waxes - candelilla wax, carnauba wax) and exhibit interesting rheology and microstructure [5].

In last years have been reported a series of researches on successful applications of beeswax in preparing diverse biodegradable films and coatings [6].

Bees wax is soft, biodegradable and a considerable viable absorbent. It is used to create a cover around the materials as a hydrophobic layer [7].

The study aims to produce the beeswax/mint essential oil emulsions and to analyze a few of its physicalchemical and quality characteristics.

\section{EXPERIMENTAL PART}

\section{Materials and methods}

- Basic materials for emulsions preparation: raw and auxiliary materials

For all experimental researches, it was used as basic raw matter the essential mint oil received from the Turkish company Doğal Destek.

As auxiliary materials, there were used: (i) beeswax purchased from a private apiary in the Northeast region of Romania; (ii) glycerin purchased from SC Elemental SRL, Romania, and (iii) Tween 80 (Merck, Germany). 
All other chemical reagents used for analytical analysis were of analytical purity (p.a.), being purchased from Romanian companies (e.g., Chemical Company S.A., lasi, RO), or from abroad (Sigma Co., or Merck Co.).

\section{- Emulsion preparation methodology}

The beeswax was melted with a $700 \mathrm{rpm}$ rate at a temperature of $65^{\circ} \mathrm{C}$, over which distilled water was added at $63^{\circ} \mathrm{C}$ to form the wax/water system. Tween 80 emulsifier was added to the wax/water system, and the system was maintained under stirring for 10 minutes at $63^{\circ} \mathrm{C}$, after which glycerol was added. After complete homogenization, the system was cooled to $40^{\circ} \mathrm{C}$, over which the mint essential oil was added dropwise. There were prepared series of emulsions $\left(M_{j}\right)$ which are different due to varying ratios of wax/essential oil used (there were selected as representative series $-M_{2}, M_{3}, M_{6}$ and $M_{7}$ emulsions having the ratio wax/oil varying in range of $1: 2 ; 1: 1.3$; 1:5; and 1:6).

The prepared esential mint oil-based emulsions were analyzed and characterized further especially for its stability and transformation degree.

\section{Analysis methods}

\section{- Emulsions appearance}

The appearance of the four prepared emulsions was visually and microscopically analyzed using a KRÜSS optical microscope equipped with a NIKON Coolpix P 5100 photo digital camera.

- $p H$ determination

Emulsion $\mathrm{pH}$ was directly measured using a HANNA portable $\mathrm{pH}$-meter immersed in the prepared nondiluted emulsion $\left(M_{j}\right)$.

\section{- Density determination}

All measurements were performed directly using an Anton Paar DMA 4500 Density Meter (Anton Paar $\mathrm{GmbH}$, Granz, Austria) at three different temperatures of $19^{\circ}, 20^{\circ}$ and $25^{\circ} \mathrm{C}$. For each temperature, there were performed at least six till eleven measurements and calculated the mean value of density at specific temperature. This mean value was reported in our work.

- Determination of the acidity index (Al)

Around $2.5 \mathrm{~g}$ of emulsion sample (weighted with precision of $0.001 \mathrm{~g}$ ) was contacted with $12.5 \mathrm{~mL}$ of chloroform and $12.5 \mathrm{~mL}$ of ethylic alcohol. After stirring, there were added a few drops of phenolphthalein indicator and the obtained solution was titrated under stirring with potassium hydroxide $(0.1 \mathrm{M} \mathrm{KOH})$ till a pink color obtained, stable at least $1 \mathrm{~min}$. For calcula tion of the acidity index $(A /)$ it was used the relation (1):

$$
A I=\frac{V_{\mathrm{KOH}} \cdot M_{\mathrm{KOH}} \cdot 56.11}{m}\left[\frac{\mathrm{mg} \text { of } \mathrm{KOH}}{\mathrm{g} \text { of emulsion }}\right]
$$

where: $\mathrm{Al}$ - the acidity index (mg $\mathrm{KOH} / \mathrm{g}$ of emulsion); $\mathrm{V}_{\mathrm{KOH}}$ - the volume of $\mathrm{KOH}$ consumed at titration (mL); $M_{K O H}$ - the concentration of $\mathrm{KOH}$ solution (mol/L); 56.11 - molecular weight of $\mathrm{KOH}(\mathrm{g} / \mathrm{mol})$ and $m$ - sample mass $(\mathrm{g})$.
- Determination of the peroxide index (PI)

In a closed glass vessel was weighed around 1-2 g of emulsion which was contacted with $5 \mathrm{~mL}$ of chloroform, $7.5 \mathrm{~mL}$ of glacial acetic acid and $1 \mathrm{~mL}$ of $10 \%$ $\mathrm{KI}$. The closed vessel was stirred for $1 \mathrm{~min}$ and after set in a dark place for $15 \mathrm{~min}$. It was added $37.5 \mathrm{~mL}$ of distilled water and, after stirring, was introduced starch solution till a dark stable blue color appears. The formed iodine is titrated with sodium thiosulfate $\left(0.05 \mathrm{~N} \mathrm{Na}_{2} \mathrm{~S}_{2} \mathrm{O}_{3}\right)$. A control titration is performed in parallel with the basic determination. For calculation of the peroxide index $(P l)$ it was considered the following relation:

$$
P I=\frac{\left(V_{\text {ref }}-V\right) \cdot 1000}{m}\left[\frac{\mathrm{mmol} \text { of peroxide }}{\mathrm{g} \text { of emulsion }}\right]
$$

where: $P I$ is the peroxide index (mol of peroxide/kg of emulsion), $V_{\text {ref }}$ - volume of $\mathrm{Na}_{2} \mathrm{~S}_{2} \mathrm{O}_{3}$ solution consumed at titration of control sample $(\mathrm{mL}), V$ - volume of $\mathrm{Na}_{2} \mathrm{~S}_{2} \mathrm{O}_{3}$ solution consumed at titration of analyzed emulsion sample ( $\mathrm{mL}), \mathrm{N}_{\mathrm{Na}_{2} \mathrm{~S}_{2} \mathrm{O}_{3}}$ - normal concentration of sodium thiosulfate solution (val/L), 1000 - recalculation coefficient of [mol of peroxide/g] in [mol of peroxide/kg] and $m$ - sample mass $(\mathrm{g})$.

- Determination of conjugated diene or triene concentration

The method is based on the absorbance measurement at a fixed wavelength in UV field for a constant mass of emulsion sample, i.e. 236, or $267 \mathrm{~nm}$ for diene and $273 \mathrm{~nm}$ for conjugated triene [8]. A emulsion sample of $0.1 \mathrm{~g}$ was diluted with distilled water till $25 \mathrm{~mL}$ in a volumetric flask. The absorbance measurement of emulsion sample was performed at Camspecspectrophotometer M 500. The value for conjugated diene (CD) and triene (CT) concentration is calculated as in relation (3) or (4):

$$
\begin{aligned}
& C_{C D}=\frac{A_{236 / 267} \cdot\left(2.5 \cdot 10^{4}\right)}{(\varepsilon \cdot l) / m} \\
& C_{C T}=\frac{A_{273} \cdot\left(2.5 \cdot 10^{4}\right)}{(\varepsilon \cdot l) / m}
\end{aligned}
$$

where: $C_{C D}-$ molar concentration of conjugated diene (mol $/ \mathrm{kg}$, or $\mathrm{mmol} / \mathrm{g}$ of emulsion), $C_{C T}-$ molar concentration of conjugated triene $\left(\mathrm{mmol} / \mathrm{cm}^{-3}\right)$, $A_{236 / 267}$ or $A_{273}$ - absorbance of diluted emulsion at 236 , or $267 \mathrm{~nm}$, and $273 \mathrm{~nm}, \varepsilon-$ molar absorbance (extinction coefficient) for linoleic acid hydroperoxide $\left(\varepsilon=2.525 \cdot 10^{4} \mathrm{M}^{-1} \cdot \mathrm{cm}^{-3}\right), I-$ cuvette length $(\mathrm{I}=1 \mathrm{~cm})$ and $m$ - sample mass $(\mathrm{g})$.

\section{RESULTS AND DISCUSSIONS}

\section{Emulsion appearance}

Emulsions appearance is presented in figure 1.

According to microscopic images, the dispersed molecule phase is presented as a compact, dense small globule mass. Related to visual images, emulsions $\mathrm{M}_{2}$ and $\mathrm{M}_{3}$ are homogeneous, white, without agglomerations of particles and easily handle. Emulsions $\mathrm{M}_{6}$ and $\mathrm{M}_{7}$ are translucent and free of particles in suspension. 


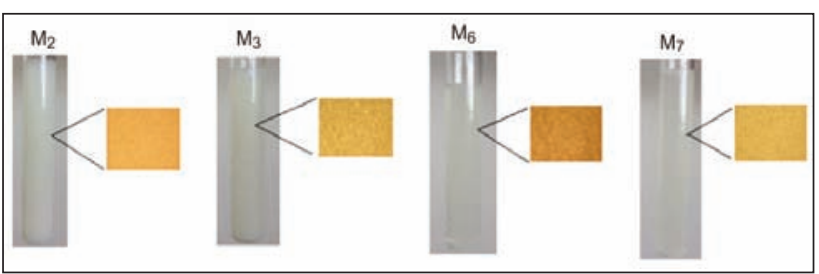

Fig. 1. Emulsions appearance

\section{Physical-chemical analysis of emulsions}

The physical-chemical properties of emulsions play a special role in preparation and further utilization of $M_{i}$ emulsions based on mint essential oil and are dependent of the chemical and structural composition. Therefore, there are necessary serious investigations for selection of a few emulsion compositions with increased value and physical, oxidative and microbiological stability. In this context, there were determined a few basic quality indices of prepared $M_{i}$ emulsions according with the international approved standard norms for cosmetic and food products.

The quality indices were determined at room temperature $\left(19-22^{\circ} \mathrm{C}\right)$ during the period of emulsions storage for at least 4 weeks.

The selection of emulsion composition was performed for obtaining an optimal ratio of poly unsaturated fatty acids in triglycerides with curative-prophylactic properties, good application on textile fabrics and assurance of emulsion resistance to different oxidations and also obtaining of an acceptable acidity (aggression) on contact with skin.

In table 1 are presented some values of physicalchemical quality indicators of the investigated $M_{i}$ emulsions.
The general physical-chemical quality indicators of the four investigated $M_{i}$ emulsions were analyzed being in range of $67.26-78.9 \%$ for separated aqueous phase, $21.21-32.26 \%$ for separated fatty phase (organic phase), 3.5-4.9 for $\mathrm{pH}, 1.0204-1.0310$ $\mathrm{g} / \mathrm{cm}^{3}$ for average absolute density at $19^{\circ} \mathrm{C}$, $1.0193-1.0307 \mathrm{~g} / \mathrm{cm}^{3}$ for mean density at $20^{\circ} \mathrm{C}$ and $1.0171-1.0299 \mathrm{~g} / \mathrm{cm}^{3}$ for mean density at $25^{\circ} \mathrm{C}$. All these characteristics are corresponding to the standardized norms in cosmetic products.

During the storage period, the prepared $M_{i}$ emulsions are supposed to possible degradation processes which can affect their quality. Usually, the emulsions can be slowly oxidized and converted in a complex organic system with a high number of components due to all oxidation steps (i.e. initiation, development and breaking of different macromolecular chains).

To analyze the in-time variation of prepared emulsions' quality is one of the important aim of this work. That is why it is important to establish the dynamic of primary oxidation products formed (i.e. hydroperoxides) during the storage of $M_{i}$ emulsions, considering especially the acidity index $(A l)$, peroxide index $(P I)$, conjugated diene $(C D)$ and triene $(C T)$ concentrations. The analysis is performed for a period of 4 weeks at room temperature $\left(19-23^{\circ} \mathrm{C}\right)$, in absence of light only in the night period.

The experimental results are summarized in table 2 . In period of emulsions storage can take place the oxidative and hydrolytic degradation which is characterized by formation of oxidation and hydrolysis products, expressed by the value of free fatty acids or fatty phase separation, and acidity index.

The value of acidity index in the four investigated $M_{i}$ emulsions was varied in 4 weeks between 1.121 and

Table 1

\begin{tabular}{|c|c|c|c|c|}
\hline \multicolumn{5}{|c|}{ SOME PHYSICAL-CHEMICAL QUALITY INDICES OF INVESTIGATED EMULSIONS } \\
\hline Physical-chemical quality indicators & $M_{2}$ & $M_{3}$ & $M_{6}$ & $M_{7}$ \\
\hline Aqueous phase, [\%] & 78.79 & 69.70 & 67.26 & 77.50 \\
\hline Fattyphase (organic phase), [\%] & 21.21 & 30.30 & 32.26 & 22.50 \\
\hline $\mathrm{pH}\left(\right.$ room temperature, $\left.\mathrm{t}=23.7^{\circ} \mathrm{C}\right)$ & $3.5 \pm 0.3$ & $4.8 \pm 0.2$ & $5.0 \pm 0.2$ & $4.9 \pm 0.2$ \\
\hline $\begin{array}{l}\text { Density (absolute, mean value), }\left[\mathrm{g} / \mathrm{cm}^{3}\right] \\
\qquad \begin{array}{c}19^{\circ} \mathrm{C} \\
20^{\circ} \mathrm{C} \\
25^{\circ} \mathrm{C}\end{array}\end{array}$ & $\begin{array}{l}1.0310 \\
1.0307 \\
1.0299\end{array}$ & $\begin{array}{l}1.0294 \\
1.0294 \\
1.0283\end{array}$ & $\begin{array}{l}1.0204 \\
1.0193 \\
1.0171\end{array}$ & $\begin{array}{l}1.0252 \\
1.0240 \\
1.0225\end{array}$ \\
\hline Acidity index, [mg KOH/g of emulsion] & 1.1420 & 2.2716 & 0.8672 & 0.8944 \\
\hline Peroxide index, [mmol/g of emulsion] & 6.7895 & 6.1627 & 5.7306 & 2.8020 \\
\hline Diene concentration, [ $\mu \mathrm{mol} / \mathrm{g}$ of emulsion] & 2.998 & 9.370 & 3.840 & 1.856 \\
\hline Conjugated triene concentration, $[\mu \mathrm{mol} / \mathrm{g}]$ & 2.539 & 8.125 & 2.674 & 1.248 \\
\hline $\begin{array}{l}\text { Stability in a month, [\%] } \\
1-3 \text { days } \\
4 \text { days } \\
1 \text { week } \\
2 \text { weeks } \\
3 \text { weeks }\end{array}$ & $\begin{array}{l}\text { Stable } \\
78.89 \\
50.00 \\
31.30 \\
21.21\end{array}$ & $\begin{array}{l}\text { Stable } \\
\text { Stable } \\
69.70 \\
50.00 \\
30.21\end{array}$ & $\begin{array}{l}\text { Stable } \\
\text { Stable } \\
\text { Stable } \\
\text { Stable } \\
\text { Stable }\end{array}$ & $\begin{array}{l}\text { Stable } \\
78.89 \\
50.00 \\
30.30 \\
22.21\end{array}$ \\
\hline
\end{tabular}


ACCUMULATION OF PRIMARY LIPIDIC OXIDATION PRODUCTS IN PERIOD OF EMULSIONS STORAGE

\begin{tabular}{|c|c|c|c|c|c|}
\hline Physical-chemical quality indicators & Storage period & $M_{2}$ & $M_{3}$ & $M_{6}$ & $M_{7}$ \\
\hline $\begin{array}{c}\text { Acidity index }(A l) \\
\text { [mg KOH/g of emulsion] }\end{array}$ & $\begin{array}{c}1 \text { week } \\
2 \text { weeks } \\
3 \text { weeks } \\
4 \text { weeks }\end{array}$ & $\begin{array}{l}1.121 \\
1.123 \\
1.136 \\
1.142\end{array}$ & $\begin{array}{l}2.263 \\
2.268 \\
2.270 \\
2.272\end{array}$ & $\begin{array}{l}0.862 \\
0.863 \\
0.865 \\
0.867\end{array}$ & $\begin{array}{l}0.885 \\
0.889 \\
0.892 \\
0.894\end{array}$ \\
\hline $\begin{array}{l}\text { Peroxide index }(P I) \text {, } \\
\text { [mmol/g of emulsion] }\end{array}$ & $\begin{array}{c}1 \text { week } \\
2 \text { weeks } \\
3 \text { weeks } \\
4 \text { weeks }\end{array}$ & $\begin{array}{l}6.7884 \\
6.7890 \\
6.7894 \\
6.7895 \\
\end{array}$ & $\begin{array}{l}6.1611 \\
6.1613 \\
6.1625 \\
6.1627\end{array}$ & $\begin{array}{l}5.7297 \\
5.7298 \\
5.7306 \\
5.7306\end{array}$ & $\begin{array}{l}2.7002 \\
2.8005 \\
2.8018 \\
2.8020 \\
\end{array}$ \\
\hline $\begin{array}{l}\text { Diene concentration }(C D) \\
\text { [ } \mu \mathrm{mol} / \mathrm{g} \text { of emulsion] }\end{array}$ & $\begin{array}{c}1 \text { week } \\
2 \text { weeks } \\
3 \text { weeks } \\
4 \text { weeks }\end{array}$ & $\begin{array}{l}2.686 \\
2.712 \\
2.834 \\
2.998\end{array}$ & $\begin{array}{l}9.302 \\
9.325 \\
9.354 \\
9.370\end{array}$ & $\begin{array}{l}3.834 \\
3.836 \\
3.841 \\
3.840\end{array}$ & $\begin{array}{l}1.611 \\
1.618 \\
1.787 \\
1.856\end{array}$ \\
\hline $\begin{array}{l}\text { Conjugated triene concentration }(C T) \text {, } \\
{[\mu \mathrm{mol} / \mathrm{g} \text { of emulsion] }}\end{array}$ & $\begin{array}{c}1 \text { week } \\
2 \text { weeks } \\
3 \text { weeks } \\
4 \text { weeks }\end{array}$ & $\begin{array}{l}2.358 \\
2.404 \\
2.512 \\
2.539\end{array}$ & $\begin{array}{l}8.109 \\
8.118 \\
8.123 \\
8.125\end{array}$ & $\begin{array}{l}2.645 \\
2.659 \\
2.668 \\
2.674\end{array}$ & $\begin{array}{l}1.104 \\
1.116 \\
1.203 \\
1.248\end{array}$ \\
\hline
\end{tabular}

$1.142 \mathrm{mg} \mathrm{KOH} / \mathrm{g}$ of emulsion for $\mathrm{M}_{1}, 2.263$ and $2.272 \mathrm{mg} \mathrm{KOH} / \mathrm{g}$ of emulsion for $\mathrm{M}_{2}, 0.862$ and 0.867 $\mathrm{mg} \mathrm{KOH} / \mathrm{g}$ of emulsion for $\mathrm{M}_{6}$ and 0.885 and 0.895 $\mathrm{mg} \mathrm{KOH} / \mathrm{g}$ of emulsion for $\mathrm{M}_{7}$. Analyzing these $A I_{i}$ values of prepared mint oil-based $M_{i}$ emulsions in the period of their storage at room temperature, it can conclude that all $A l_{i}$ values increase, fact which demonstrates the accumulation of free fatty acids. The values of acidity indices $\left(A I_{i}\right)$ differ significantly, the highest being obtained for $M_{3}$ emulsion and the lowest for $M_{7}$. In addition, the fatty phase separated was the highest in the case of $M_{7}$ emulsion followed by $M_{3}$ emulsion. This fact can be explained by the high content of fatty acids with double and triple bonds, which are degraded much faster in the storage activity (at room temperature).

It is known that the presence of peroxide (hydroperoxide) in emulsion determines the degree of emulsion stability during the storage process (at room temperature). The values of peroxide index were not significantly changed after 4 weeks, varying for $M_{2}$ emulsion in range of 6.7884-6.7895 mmol/g, 6.1611$6.1627 \mathrm{mmol} / \mathrm{g}$ for $M_{3}$ emulsion, 5.7297-5.7306 $\mathrm{mmol} / \mathrm{g}$ for $M_{6}$ emulsion and $2.7002-2.8020 \mathrm{mmol} / \mathrm{g}$ for $M_{7}$ emulsion. Based on the resulted experimental data, the highest peroxide concentration was performed in the case of $M_{2}$ which was found also with lowest stability in time at room temperature, followed by $M_{7}$ emulsion.

For the study of lipids oxidation, it must be analyzed the variation of conjugated diene and triene concentration which are produced from unsaturated fatty acids as result of hydroperoxide formation due to rearrangements of double bonds. The formed conjugated diene presents an intense absorption at the wave length of $234 \mathrm{~nm}$ or $267 \mathrm{~nm}$, and in case of triene the intense absorption is registered at $273 \mathrm{~nm}$. An increase of UV absorption indicates the formation of primary oxidation products in the investigated $M_{i}$ emulsions. This fact concludes clearly that the storage of $M_{i}$ emulsion at room temperature acts in direction of increasing the conjugated diene and triene concentrations. The highest value during 4 weeks of storage at room temperature was achieved for $M_{3}$ emulsion, i.e. 9.303-9.370 $\mu \mathrm{mol} / \mathrm{g}$ of emulsion for diene concentration and $8.109-8.125 \mu \mathrm{mol} / \mathrm{g}$ of emulsion for triene concentration, and the lowest for $M_{7}$ emulsion, i.e. 1.611-1.856 $\mu \mathrm{mol} / \mathrm{g}$ of emulsion for the diene concentration and 1.104-1.248 $\mu \mathrm{mol} / \mathrm{g}$ of emulsion for the triene content.

In addition, the peroxides are instable compounds, but in the process of emulsion storage these can be decomposed forming secondary oxidation products as aldehydes, ketones and its derivates with carbonyl chain of different lengths. The peroxides have no direct influence on sensory indices of emulsions, but if aldehydes and ketones are formed, these have rancid odor. In the case of $M_{i}$ emulsions it was found no such a rancid odor, being indicated that secondary oxidation products were not formed during the period of 4 weeks of emulsion storage at room temperature.

\section{CONCLUSIONS}

The physical-chemical quality indices of investigated $M_{i}$ emulsions based on mint essential oil were indicated that the highest stability had the $M_{6}$ emulsion followed by $\mathrm{M}_{3}$ emulsion.

The comparative analysis of experimental results performed for the acidity index, peroxide index, conjugated diene and triene concentration were permitted some preliminary information concerning the dynamic of $M_{i}$ emulsion degradation during the storage activity at room temperature for a time period of 4 weeks. The results indicated the formation of primary oxidation products (hydroperoxides), but no formation of secondary oxidation products (aldehydes and ketones) with their specific rancid odor.

The general physical-chemical indicators of investigated $M_{i}$ emulsions were found corresponding with 
the standardized norms in cosmetics and textiles for topical applications.

\section{ACKNOWLEDGEMENTS}

This work was supported by a grant of the Romanian National Authority for Scientific Research and Innovation,
CCCDI - UEFISCDI, project number 29/2018 COFUNDMANUNET III-AromaTex, project title "Manufacturing of value-added textiles for aromatherapy and skin care benefits“, within PNCDI III.

\title{
BIBLIOGRAPHY
}

[1] Bakry, A.M., Abbas, S., Ali, B., Majeed, H., Abouelwafa, M.Y., Liang, L. Microencapsulation of oils: A Comprehensive review of benefits, techniques, and applications. In: Bioengineering, 2017, vol. 4, p. 74.

[2] Horrocks, A.R., Anand, S.C. Hand-book of Technical Textiles. Published by Woodhead Publishing Limited in association with The Textile Institute, 2010.

[3] Montenegro, L., Lai, F., Offerta, A., Sarpietro, M.G., Micicche, L., Maccioni, A.M., Valenti, D., Fadda, A.M. From nanoemulsions to nanostructured lipid carriers: A relevant development in dermal delivery of drugs and cosmetics. In: Journal of Drug Delivery Science and Technology, 2016, vol. 32, p. 100.

[4] Radu, C.D., Cerempei, A., Salariu, M., Parteni, O., Ulea, E., Campagne, C. The potential of improving medical textile for cutaneous diseases. In: IOP Conference Series: Materials Science and Engineering, 2017, vol. 254, pp. 1-8.

[5] Milanovic, J., Manojlovic, V., Levic, S., Rajic, N., Nedovic, V., Bugarski, B. Microencapsulation of flavors in Carnauba Wax. In: Sensors, 2010, vol. 10, p. 901.

[6] Khanzadi, M., Jafari, S.M., Mirzaei, H., Chegini, F.K., Maghsoudlou, Y., Dehnad, D. Physical and mechanical properties in biodegradable films of whey protein concentrate-pullulan by application of beeswax. In: Carbohydrate Polymers, 2015, vol. 118, p. 24.

[7] Namdariyan, R., Farahbakhsh, A., Golestani, H.A. Encapsulation ZnO nanoparticles by using beeswax. In: Proceedings of the 2nd International Conference on Oil, Gas and Petrochemical Issues(ICOGPI'2013), 2013, Kuala Lumpur (Malaysia), p. 67.

[8] Capcanari, T. Technologies of preparation of food emulsions from mixtures of sunflower oils and graves oil. In: Ph.D. Thesis, Technical University of Republic of Moldova, 2012, p. 47.

[9] Banu, C., Quality and quality control of food products. AGIR Ed., Bucureşti, Romania, 2002, p. 55.

\author{
Authors: \\ Lecturer PhD. Eng. ANGELA DĂNILĂ ${ }^{1}$ \\ Associate Prof. PhD. Eng. CARMEN ZAHARIA ${ }^{2}$ \\ Prof. PhD. Eng. DANIELA ŞUTEU ${ }^{2}$ \\ Lecturer $P h D$. Eng. EMIL IOAN MUREŞAN ${ }^{2}$ \\ Prof. PhD. Eng. GABRIELA LISĂ ${ }^{2}$ \\ SINEM YAPRAK KARAVANA ${ }^{3}$ \\ ALI TOPRAK ${ }^{4}$ \\ PhD. Eng. ALINA POPESCU 5 \\ PhD. Eng. LAURA CHIRILĂ ${ }^{5}$
}

1 "Gheorghe Asachi" Technical University of Iasi, Faculty of Textile Leather Engineering and Industrial Management, lasi, 29 Prof. Dr. Doc. Dimitrie Mangeron street, Romania

2 "Gheorghe Asachi" Technical University of lasi, Faculty of Chemical Engineering and Environmental Protection,

Department of Environmental Engineering and Management,

73 Prof. Dr. Docent D. Mangeron Blvd, 700050 - lasi, Romania

${ }^{3}$ Ege University, Faculty of Pharmacy, Department of Pharmaceutical Technology, 35100 Bornova, Izmir, Turkey

${ }^{4}$ DoğalDestekÜrünleriAraştırmaSanayiveTicaret A.Ş., AtburgazıMah. Abdilpekçi Cad. No:70 Söke-AYDIN Turkey

${ }^{5}$ The National Research-Development Institute for Textiles and Leather Research, Bucuresti, Romania

e-mail: angela.cerempei@yahoo.com; czah@ch.uiasi.ro;dsuteu@ch.tuiasi.ro; eimuresan@yahoo.co.uk; gapreot@ch.tuiasi.ro;sinem.yaprak.karavana@ege.edu.tr; atoprak@dogaldestek.com.tr; alina.popescu@certex.ro; laura.chirila@certex.ro

Corresponding author:

CARMEN ZAHARIA

email: czah@ch.uiasi.ro or czaharia2003@yahoo.com 